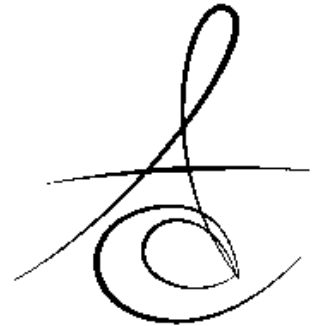

Makale Kodu/Article code: 1408

Makale Gönderilme tarihi: 21.11 .2013

Kabul Tarihi: 27.05.2014

\section{RETREATMENT OF ROOT CANAL FILLINGS PERFORMED WITH A CALCIUM SILICATE BASED ROOT CANAL SEALER AND GUTTA-PERCHA WITH DIFFERENT ROOT CANAL SOLVENTS}

\section{KALSİYUM SİLİKAT İÇERİKLİ BİR KÖK KANAL PATI VE GUTTA-PERKA KULLANILARAK YAPILMIŞ KÖK KANAL DOLGULARININ FARKLI KÖK KANAL SOLVENTLERİ İLE YENİDEN KANAL TEDAVİSİ}

\author{
Dr. Yakup ÜSTÜN*
}

Doç. Dr.Burak SAĞSEN $* * *$

\section{ABSTRACT}

Aim: The aim of this study was to evaluate the efficiencies of different conventional

solvents on the removal of root fillings performed with MTA Fillapex root canal sealer and

gutta- percha.

Material and Method: Forty-five maxillary central incisors human teeth were included. Sample lengths were adjusted to $16 \mathrm{~mm}$ and root canal preparations were performed with $\mathrm{K} 3$ instruments up to 30/.04 size. MTA Fillapex ${ }^{\circ}$ root canal sealer and gutta percha were used to obturate the canals with cold lateral condensation technique. The teeth were stored for 1 week at $37^{\circ} \mathrm{C}$ in $100 \%$ relative humidity. Specimens were randomly assigned into three groups (n:15): G1: Resosolv, G2: Endosolv E and G3: Guttasolv. 35/.04 K3 instruments were used as the final retreatment instruments. Final irrigation was performed and root canals were dried. The teeth were split along their long axis and operating microscope at 10x magnification was used to evaluate the amount of remaining root filling material. Samples were then scored. SEM and EDS analysis were used to enhance the accuracy of evaluations. Data were subjected to statistical interpretation using Kruskal-Wallis test at a 95\% confidence level $(p<0.05)$.

Results: There were no statistically significant differences among the three experimental groups in the apical, middle and coronal thirds of the root canals $(p>0.05)$. Intra group comparisons showed that apical, middle and coronal thirds of each group showed no significant differences among themselves ( $p>0.05)$.

Conclusion: Root fillings performed with MTA

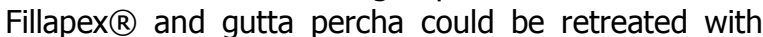
the solvents used in the study.

Key Words: Endodontics, Retreatment, Root Canal Therapy

\section{ÖZET}

Amaç: Bu çalışmanın amacı, MTA Fillapex kök kanal patı ve güta-perka-ile yapılmış kanal dolgularının uzaklaştırılmasında farklı geleneksel solventlerin etkinliğini değerlendirmekti.

Gereç ve Yöntem: 45 maksiller santral kesici insan dişi çalışmaya dahil edildi. Örneklerin boyları 16 mm'ye ayarlandı ve kök kanal preparasyonları K3 enstrümanlarıyla 30/.04 boyuta ulaşılıncaya kadar yapıldı. Kök kanallarının doldurulması, soğuk lateral kondensasyon tekniği kullanılarak MTA Fillapex kök kanal patı ve güta perka ile

gerçekleştirildi. Dişler 1 hafta süresince $37^{\circ} C^{\prime}$ de ve $\% 100$ nemli ortamda saklandı. Örnekler

rastgele 3 gruba ayrıldı (n:15): G1: Resosolv G2: Endosolv E G3: Guttasolv. 35/.04 K3 enstrümanları son retreatment enstrümanları olarak kullanıldı. Son irrigasyon ve kurulama yapıldı. Dişler uzun eksenleri boyunca ikiye ayrıldı ve artık kök kanal dolgu maddesi operasyon mikroskobuyla 10X büyütmede incelendi. Örnekler skorlandı. Değerlendirmenin doğruluğunu arttırmak amacıyla SEM ve EDS analizleri yapıldı. \%95 güven seviyesinde $(p<0.05)$ Kruskal-Wallis testi ile istatistiksel analiz yapıldı.

Bulgular: Üç grubun apikal, orta ve koronal üçlüleri arasında yapılan istatistiksel karşılaştırmada anlamlı farklılık yoktu ( $p>0.05)$. Grupların kendi içinde apikal, orta ve koronal üçlülerinin karşılaştırmasında istatistiksel olarak anlamlı farklılık yoktu ( $p>0.05)$.

Sonuç: MTA Fillapex ve gutta-perka ile yapılan kanal dolgularının yeniden kanal tedavisinde bu çalışmada kullanılan solventler kullanılabilir.

Anahtar Kelimeler: Endodonti, Yeniden Kanal Tedavisi, Kök Kanal Tedavisi

\footnotetext{
* Department of Endodontics, Faculty of Dentistry, Erciyes University,

** Department of Endodontics, Faculty of Dentistry, Erciyes University,

*** Department of of Endodontics, Faculty of Dentistry, Erciyes University,

*Çalışma, Türk Endodonti Derneği 11. Uluslararası Endodonti Kongresi 27-28 Nisan 2012, İstanbul Kongresinde poster bildirisi olarak sunulmuştur.
} 


\section{INTRODUCTION}

The success rate of root canal treatment is shown to be nearly $90 \% .^{1}$ However, failure can occur despite careful treatment methods with high and strict standards. ${ }^{2}$ Several factors, such as; inadequate canal preparation/obturation and procedural errors could be responsible for occasional failures of root canal treatment. Root canal retreatment is often required when primary treatment has failed. ${ }^{3}$ Endodontic failures generally occur in case of inadequate obturation or coronal leakage. ${ }^{4,5}$ As a result of endodontic failures the need for orthograde retreatment arises.

Non-surgical retreatment is preferred as the first choice to correct recent problems in the previous endodontic treatment and involves three- dimensional cleaning and obturation of root canal. ${ }^{6}$ Many techniques, such as rotary Ni-Ti instruments ${ }^{7-9}, \operatorname{laser}^{10}$, ultrasonic instruments ${ }^{11}$, heated pluggers ${ }^{12}$ and hand instruments combined with different chemical solvents such as chloroform, eucalyptol, turpentine, orange oil $^{13-15}$ have been suggested for the removal of root canal filling materials from the root canals. However, in retreatment cases, entire removal of root fillings from the root canal walls could not be achieved in any technique. $7,8,16,17$ The failure in removal of root canal filling may result in the survival of residual bacteria, which may cause persistant periapical disease and eventual endodontic failure. ${ }^{18}$ Microorganisms can survive even in apparently well treated teeth in dentinal tubules, canal irregularities, deltas and isthmus areas. ${ }^{19}$ If residual microorganisms remain completely entombed in the root canal system, periradicular healing should occur. Sealing off all potential routes of microbial escape from the root canal system is the goal of both non-surgical and surgical retreatment. ${ }^{20}$ Several investigations have shown that the clinical usage of different chemical solvents facilitated the retreatment procedure by dissolving gutta percha and sealer. ${ }^{21,} 22$ In retreatment cases; clinicians are generally unable to determine the type of recently used endodontic filling materials; hence, an ideal solvent should be effective on a large variety of filling materials. ${ }^{23}$

Endosolv E (Septodont, Paris, France), Guttasolv (Septodont, Paris, France) and Resosolv (Pierre Rolland, Merignac, France) are commonly used as solvents including tetrachloroethylene, eucalyptol, dimethylfor- mamide respectively. There are different studies about clinical efficacy of these solvents. ${ }^{21,23-25}$

MTA Fillapex $\AA$ is a recently introduced MTAbased root canal sealer. It contains calcium silicate, salicylate resin, diluting resins, natural resin, nanoparticulated resin, bismuth trioxide and remarkable content of MTA that has many favorable effects. ${ }^{26}$ According to the manufacturer it has high radio-opacity, low solubility and low expansion during setting, and it promotes deposition of hard tissue. ${ }^{27}$ In the literature there are several studies evaluating the push out bond strength ${ }^{28}$, cytotoxicity ${ }^{29}$, genotoxicity ${ }^{29}$, solubility ${ }^{30}$ and fracture resistance of MTA Fillapex. ${ }^{31}$ However, there is no study concerning the retreatment of root fillings performed with MTA Fillapex.

The aim of the present study was to evaluate the efficiencies of different conventional solvents on the removal of root fillings performed with MTA Fillapex root canal sealer and gutta percha.

\section{MATERIAL AND METHODS}

Forty-five maxillary central incisor human teeth with fully formed apices were included in the study. The teeth were immersed in $10 \%$ formalin solution until use.

\section{Sample Preparation}

The crowns were removed with a water cooled diamond bur and the sample lengths were adjusted to $16 \mathrm{~mm}$. The working length was determined by subtracting $1 \mathrm{~mm}$ from the length that a \# $8 \mathrm{~K}$-file was visible at the apical foramen. All root canal preparations were performed with a torque and speed controlled endodontic motor (Dentsply, Maillefer, Ballaigues, Switzerland) using $\mathrm{K} 3 \mathrm{Ni}-\mathrm{Ti}$ rotary instruments (Sybron Dental Specialties/ Kerr Corporation, Orange, CA, USA). Final apical enlargement was done with $30 / .04 \mathrm{~K} 3 \mathrm{Ni}-\mathrm{Ti}$ rotary instruments (The instrument sequence was 40/.06, $35 / .04$ and 30/.04). Irrigation was performed conventionally with $3 \mathrm{ml}$ of $2 \% \mathrm{NaOCl}$ between each instrument. A final rinse with $5 \mathrm{ml}$ of $2 \% \mathrm{NaOCl}, 5 \mathrm{ml}$ of $17 \%$ EDTA and $5 \mathrm{ml}$ of distilled water was performed and the root canals were dried with paper points. 
MTA Fillapex $®$ (Angelus, Londrina, Brazil) root canal sealer was prepared according to manufacturer instructions and the master apical gutta percha cone was coated with sealer and introduced into the root canal. Root canal obturation was performed with cold lateral condensation technique. The roots were radiographically checked in buccolingual and mesiodistal directions to assure the adequacy of the root filling. Then, the access cavities of the specimens were sealed with a temporary filling material (Cavit, ESPE, Seefeld, Germany). The teeth were stored for 1 week at $37{ }^{\circ} \mathrm{C}$ in $100 \%$ relative humidity to allow complete setting of the sealer.

\section{Retreatment Procedures}

The temporary fillings were removed. Specimens were randomly assigned into three groups according to the solvents used during the retreatment procedure $(n=15)$. Group 1: Resosolv Group 2: Endosolv E Group 3: Guttasolv

The coronal part of each root $(3 \mathrm{~mm})$ was removed using a No: 3 Gates Glidden (GG) (Mani Inc., Tochigi, Japan) to create a reservoir for the solvents used in each group and $0.1 \mathrm{ml}$ of solvent were placed in the coronal part of the canal for 1 minute to soften the gutta-percha. Then 20/.06 K3 instrument was used in removal of root fillings at coronal and middle thirds of the roots, then $30 / .04$ and $35 / .04 \mathrm{~K} 3 \mathrm{Ni}-\mathrm{Ti}$ rotary instrument was used in working lengths of the canals to remove the root canal filling materials. When 35/.04 K3 instrument reached the working length, 0.2 $\mathrm{ml}$ of the solvent was added into the root canal and 35/.04 K3 instrument was used at the working length with circular movements. Between each instrument root canals were irrigated with $3 \mathrm{ml}$ of $2 \% \mathrm{NaOCl}$. Final irrigations were performed with $5 \mathrm{ml}$ of $2 \%$ $\mathrm{NaOCl}, 5 \mathrm{ml}$ of $17 \%$ EDTA and $5 \mathrm{ml}$ of distilled water and the root canals were dried with paper points.

\section{Microscopic Evaluation}

The teeth were grooved with a water-cooled diamond bur on the buccal and lingual surfaces and split along their long axis using a hammer and chisel. An operating microscope (OPMI Pico; Carl Zeiss, Germany) at 10x magnification was used to evaluate the amount of remaining root filling material as used in the study of Kfir et al. ${ }^{32}$ A scoring system that was defined by Kosti et al. ${ }^{33}$ was used to assess the quantity of the remaining root canal filling materials on the canal walls;
Score 0: no gutta-percha and no sealer,

Score 1: debris of sealer,

Score 2: debris of sealer and gutta-percha,

Score 3: severe debris of sealer and guttapercha. $^{33}$

\section{SEM Evaluation}

One sample from each score group was chosen for SEM evaluation. Fractured halves of each root were mounted on aluminium stubs, vacuum-dried, coated with $20 \mathrm{~nm}$ of gold and then examined under SEM (Leica-Leo S440,Cambridge, UK). For enhancement of the visualization the microphotographs of selected samples were taken at $\times 400$ and $\times 2000$ magnifications from the coronal, middle and apical thirds of the roots.

\section{Energy Dispersive Spectroscopy (EDS):}

To assure the type of residues observed on the root canal walls, EDS analyze were used to determine elemental ingredient of components on selected images (Figure 2).

\section{Statistical Analysis}

Due to the fact that normality tests of distribution were failed $(p<0.05)$ and scoring system was used, data were subjected to statistical interpretation using Kruskal-Wallis test at a $95 \%$ confidence level $(p<0.05)$ by using SPSS/PC 16.0 (SPSS Inc, Chicago, IL, USA ) software.

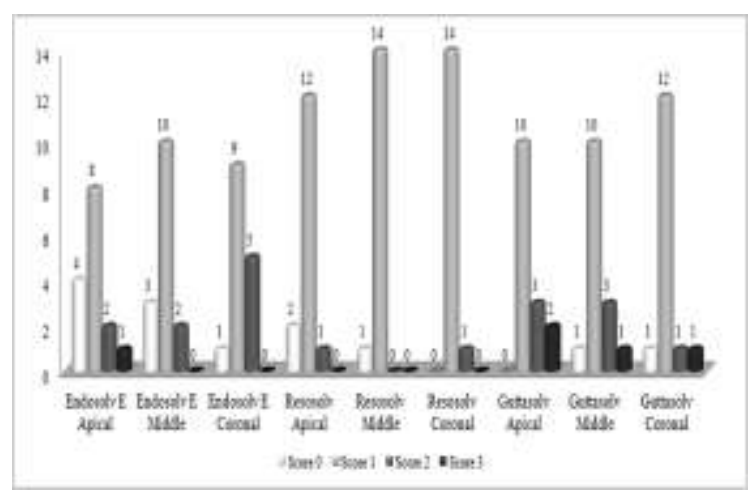

Figure 1. Score distributions of the groups. 

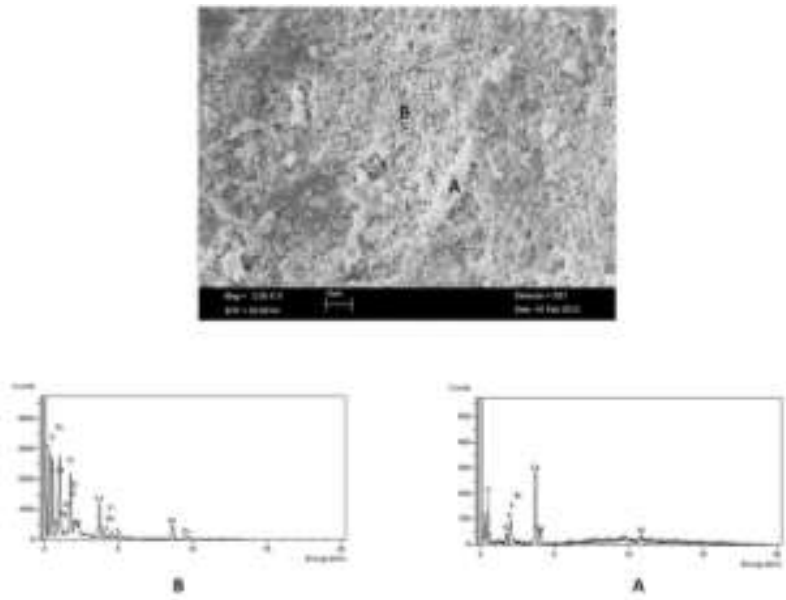

Figure 2. (A) represents the EDS Graphic of gutta percha. (B) represents the EDS Graphic of MTA Fillapex sealer.

\section{RESULTS}

In all the groups, residual filling materials were observed (Figure 1). Intergroup comparisons showed that there were no statistically significant differences among the three experimental groups in the apical, middle and coronal thirds of the root canals $(p>0.05)$ (Table 1). Intra group comparisons showed that apical, middle and coronal thirds of each group showed no significant differences among themselves $(p>0.05)$ (Table I). Score 1 (debris of sealer) was the most frequent score in all the groups. Except the middle thirds of the Resosolv groups gutta-percha remnants were found in all the groups and all root canal thirds.

Table 1. Descriptive statistics of the groups.

\begin{tabular}{lcccc}
\hline & Region & $\begin{array}{c}\text { Std. } \\
\text { Error }\end{array}$ & Median & Mean \\
\hline \multirow{3}{*}{ Endosolv E } & Apical $(* a)$ & 0.218 & 1 & 1 \\
& Middle $(* a)$ & 0.153 & 1 & 0.933 \\
& Coronal $(* a)$ & 0.153 & 1 & 1.267 \\
\multirow{5}{*}{ Resosolv } & Apical $(* a)$ & 0.118 & 1 & 0.933 \\
& Middle $(* a)$ & 0.066 & 1 & 0.933 \\
& Coronal $(* a)$ & 0.066 & 1 & 1.067 \\
\multirow{5}{*}{ Guttasolv } & Apical $(* a)$ & 0.192 & 1 & 1.467 \\
& Middle $(* a)$ & 0.182 & 1 & 1.267 \\
& Coronal $(* a)$ & 0.165 & 1 & 1.133 \\
\hline
\end{tabular}

*Same letters shows no statistical significance among the groups $(P>0.05)$.

\section{DISCUSSION}

Ideal root canal filling should be removed easily in case retreatment is necessary. Complete removal of previous root canal filling material is necessary to facilitate the optimum cleaning, disinfection and reobturation of the root canal. ${ }^{32}$ Hence, complete removal of the root canal filling from root canals with different techniques such as, instrumentation with stainless steel hand files, using heated pluggers, ultrasonic instruments and rotary nickel titanium systems have been evaluated by several authors. ${ }^{4,22,}$ 24 Up to date, there is no study evaluating the removal of root fillings performed with a calcium silicate (CaSi) based root canal sealer and gutta percha by means of 3 different solvents.

In previous studies, it has been proposed that the remaining filling material can be minimized by means of the canal enlargement that exceeds initial root filling. ${ }^{9}$, 13 In the present study, further enlargement was performed with a one size larger instrument than the master apical file of initial preparation.

Stereomicroscope was used for score evaluation as it was considered a simple, efficient method. Additionally, as in the study of Kosti et al. ${ }^{33}$ for the enhancement of the inspection, representative SEM images were taken from the experimental groups. EDS was used to verify the chemical composition of the remnants on the root canal walls (Figure 2).

MTA Fillapex consists of salicylate resin, calcium silicate resin, diluting resins, natural resin, nanoparticulated resin, bismuth trioxide and MTA. Sarkar et al..$^{34}$ suggested that release of calcium and hydroxyl ions from the set sealer will result in the formation of apatites when the material comes into contact with phosphate containing fluids. ReyesCarmona et al. ${ }^{35}$ reported that the apatite formed by MTA and phosphate-buffered saline was deposited within collagen fibrils, promoting controlled mineral nucleation on dentine, seen as the formation of an interfacial layer with tag-like structures. Sagsen et al. ${ }^{28}$ suggested that the interfacial layer with tag-like structures between MTA Fillapex and root canal dentine diminished the micro push out bond strength of the sealer; however, there is little knowledge about the retreatment of the root canals obturated with $\mathrm{CaSi}$

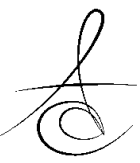


based sealers and gutta percha. Only one study gives information about retreatment of a CaSi based sealer (iRoot SP - Innovative BioCreamix Inc, Vancouver, Canada) and it is about the ability to reach the working length and regain the determined patency for each canal at elapsed time, using chloroform as the solvent. ${ }^{36}$ Chloroform is the most commonly used solvent because of its effectiveness. ${ }^{37}$ Nevertheless there are some limitations to its use, particularly because it has been suggested that chloroform might be a potential carcinogen in uncontrolled usage ${ }^{37,38}$ and chloroform leaves a fine layer or film of softened gutta-percha. ${ }^{39}$ In the present study, chloroform was not used because of the reported disadvantages. Therefore, three different solvents were used; Resosolv was chosen because of the resin ingredient of MTA Fillapex; Guttasolv was chosen for its common usage, and Endosolv $E$ consists of tetrachloroethlyne and is effective on both gutta percha and sealer components. ${ }^{40}$ Hess et al. ${ }^{36}$ reported that conventional techniques are not sufficient for full removal of $\mathrm{CaSi}$ based sealer (BC Sealer - Brasseler USA, Savannah, $\mathrm{GA}$ ), and suggested to use a new technique or a new solvent in retreatment of root fillings done with $\mathrm{CaSi}$ based sealer (BC Sealer) and gutta percha.

He et $a l^{24}$ reported that Resosolv is an effective solvent for retreatment in root canals obturated with resin based sealer and gutta percha. The Resosolv solvent could be effective on such resin ingredient of MTA Fillapex like salicylate resin, diluting resins, natural resin, nanoparticulated resin. Although, the Resosolv group showed lower score distribution than the other experimental groups, in the present study there was no statistically significant difference among the groups. This result could be related to the effect of the solvents on gutta percha. When gutta percha was softened by the Guttasolv and Endosolv E, the retreatment and cutting efficiency of rotary system could be facilitated and the residual sealer could be easily removed. In addition, during the retreatment procedure the use of one size larger instrument than the master apical file could be effective on these results. According to the results of the present study each solvent had equal efficiencies on retreatment of root fillings performed with MTA Fillapex and gutta percha. These results could be related to resin dissolving property of Resosolv, effectiveness of Endosolv $\mathrm{E}$ on both gutta percha and sealer, and also effective dissolving capacity of Guttasolv that facilitates the removal of both gutta percha and sealer.

Root fillings performed with MTA Fillapex and gutta percha could be retreated with the solvents used in the study. There were no significant differences among the groups. However, according to score distributions, the highest cleaning efficiency was observed in the Resosolv group. (Figure 1).

\section{REFERENCES}

1. Friedman S. Expected outcomes in the prevention and treatment of apical periodontitis. In: Orstavik $D$, Ford TP, editors. Essential endodontology: Prevention and treatment of apical periodontitis. Oxford: Blackwell Munksgaard; 2007. 432.

2. Siqueira JF Jr. Aetiology of root canal treatment failure: why well-treated teeth can fail. Int Endod J 2001;34:1-10.

3. de Chevigny $C$, Dao $T$, Basrani BR, Marquis V, Farzaneh M, Abitbol S, Friedman S. Treatment outcome in endodontics: the Toronto study-phases 3 and 4: orthograde retreatment. J Endod 2008;34:131-7.

4. Barletta FB, de Sousa Reis $M$, Wagner M, Borges JC, Dall'Agnol C. Computed tomography assessment of three techniques for removal of filling material. Aust Endod J 2008;34:101-5.

5. Sjogren U, Hagglund B, Sundqvist G, Wing K. Factors affecting the long-term results of endodontic treatment. J Endod 1990;16:498-504.

6. Odesjo B, Hellden L, Salonen L, Langeland K. Prevalence of previous endodontic treatment, technical standard and occurrence of periapical lesions in a randomly selected adult, general population. Endod Dent Traumatol 1990;6:265-72.

7. Hulsmann M, Bluhm V. Efficacy, cleaning ability and safety of different rotary NiTi instruments in root canal retreatment. Int Endod J 2004;37:46876.

8. Schirrmeister JF, Wrbas KT, Meyer KM, Altenburger MJ, Hellwig E. Efficacy of different rotary instruments for gutta-percha removal in root canal retreatment. J Endod 2006;32:469-72. 
9. Tasdemir T, Yildirim T, Celik D. Comparative study of removal of current endodontic fillings. J Endod 2008;34:326-9.

10. Viducic D, Jukic S, Karlovic Z, Bozic Z, Miletic I, Anic I. Removal of gutta-percha from root canals using an Nd:YAG laser. Int Endod J 2003;36:6703.

11. Krell KV, Neo J. The use of ultrasonic endodontic instrumentation in the re-treatment of a pastefilled endodontic tooth. Oral Surg Oral Med Oral Pathol 1985;60:100-2.

12. Friedman S, Mor C. The success of endodontic therapy--healing and functionality. J Calif Dent Assoc 2004;32:493-503.

13. Friedman S, Moshonov J, Trope M. Efficacy of removing glass ionomer cement, zinc oxide eugenol, and epoxy resin sealers from retreated root canals. Oral Surg Oral Med Oral Pathol 1992;73:609-12.

14. Schirrmeister JF, Wrbas KT, Schneider FH, Altenburger MJ, Hellwig E. Effectiveness of a hand file and three nickel-titanium rotary instruments for removing gutta-percha in curved root canals during retreatment. Oral Surg Oral Med Oral Pathol Oral Radiol Endod 2006;101:542-7.

15. Wilcox LR, Krell KV, Madison S, Rittman B. Endodontic retreatment: evaluation of guttapercha and sealer removal and canal reinstrumentation. J Endod 1987;13:453-7.

16. Barrieshi-Nusair KM. Gutta-percha retreatment: effectiveness of nickel-titanium rotary instruments versus stainless steel hand files. J Endod 2002;28:454-6.

17. Ferreira JJ, Rhodes JS, Ford TR. The efficacy of gutta-percha removal using ProFiles. Int Endod J 2001;34:267-74.

18. Ring J, Murray PE, Namerow KN, Moldauer BI, Garcia-Godoy F. Removing root canal obturation materials: a comparison of rotary file systems and re-treatment agents. J Am Dent Assoc 2009;140:680-8.

19. Love RM, McMillan MD, Jenkinson HF. Invasion of dentinal tubules by oral streptococci is associated with collagen recognition mediated by the antigen I/II family of polypeptides. Infect Immun 1997;65:5157-64.

20. Hargreaves K CS. Pathways of the pulp, $10^{\text {th }}$ ed. St Louis, Missouri: Mosby Elsevier; 2011.
21. Bodrumlu E, Er O, Kayaoglu G. Solubility of root canal sealers with different organic solvents. Oral Surg Oral Med Oral Pathol Oral Radiol Endod 2008;106:67-9.

22. Tanomaru-Filho M, Orlando TA, Bortoluzzi EA, Silva GF, Tanomaru JM. Solvent capacity of different substances on gutta-percha and Resilon. Braz Dent ] 2010;21:46-9.

23. Faria-Junior NB, Loiola LE, Guerreiro-Tanomaru JM, Berbert FL, Tanomaru-Filho M. Effectiveness of three solvents and two associations of solvents on gutta-percha and resilon. Braz Dent J 2011;22:414.

24. He BZ, Zhang CF, Ding RY, Lin QG. [Comparative study of resosolv and chloroform in retreatment of canal obturated with resinifying agent]. Hua Xi Kou Qiang Yi Xue Za Zhi 2004;22:474-6.

25. Martos J, Bassotto AP, Gonzalez-Rodriguez MP, Ferrer-Luque CM. Dissolving efficacy of eucalyptus and orange oil, xylol and chloroform solvents on different root canal sealers. Int Endod J 2011;44:1024-8.

26. Gençoğlu N. Yıldırım T. Furkasyon perforasyonlarında kullanılan MTA, SUPER-EBA ve Amalgam'ın mikrosızıntısının incelenmesi. Atatürk Üniv Diş Hek Fak Derg 2003-2004; 13-14: 7-12.

27. [http://www.angelus.ind.br/en/endodontics/mta_ fillapex/]

28. Sagsen B, Ustun Y, Demirbuga S, Pala K. Push-out bond strength of two new calcium silicate-based endodontic sealers to root canal dentine. Int Endod J 2011;44:1088-91.

29. Bin CV, Valera MC, Camargo SE, Rabelo SB, Silva GO, Balducci I, et al. Cytotoxicity and genotoxicity of root canal sealers based on mineral trioxide aggregate. J Endod 2012;38:495-500.

30. Borges RP, Sousa-Neto MD, Versiani MA, RachedJunior FA, De-Deus G, Miranda CE, Pecora JD. Changes in the surface of four calcium silicatecontaining endodontic materials and an epoxy resin-based sealer after a solubility test. Int Endod ] 2012;45:419-28.

31. Tanalp J, Dikbas I, Malkondu O, Ersev H, Gungor $T$, Bayirli G. Comparison of the fracture resistance of simulated immature permanent teeth using various canal filling materials and fiber posts. Dent Traumatol 2012;28:457-64. 
32. Kfir A, Tsesis I, Yakirevich E, Matalon S, Abramovitz I. The efficacy of five techniques for removing root filling material: microscopic versus radiographic evaluation. Int Endod J 2012;45:3541.

33. Kosti E, Lambrianidis T, Economides N, Neofitou C. Ex vivo study of the efficacy of $\mathrm{H}$-files and rotary $\mathrm{Ni}$ - $\mathrm{Ti}$ instruments to remove gutta-percha and four types of sealer. Int Endod J 2006;39:48-54.

34. Sarkar NK, Caicedo R, Ritwik P, Moiseyeva R, Kawashima I. Physicochemical basis of the biologic properties of mineral trioxide aggregate. J Endod 2005;31:97-100.

35. Reyes-Carmona JF, Felippe MS, Felippe WT. Biomineralization ability and interaction of mineral trioxide aggregate and white portland cement with dentin in a phosphate-containing fluid. J Endod 2009;35:731-6.

36. Hess D, Solomon E, Spears R, He J. Retreatability of a bioceramic root canal sealing material. J Endod 2011;37:1547-9.

37. Takahashi CM, Cunha RS, de Martin AS, Fontana $\mathrm{CE}$, Silveira CF, da Silveira Bueno CE. In vitro evaluation of the effectiveness of ProTaper universal rotary retreatment system for guttapercha removal with or without a solvent. J Endod 2009;35:1580-3.

38. McDonald MN, Vire DE. Chloroform in the endodontic operatory. J Endod 1992;18:301-3.

39. Sae-Lim V, Rajamanickam I, Lim BK, Lee HL. Effectiveness of ProFile .04 taper rotary instruments in endodontic retreatment. J Endod 2000;26:100-4.

40. Tamse A, Unger U, Metzger Z, Rosenberg M. Gutta-percha solvents--a comparative study. J Endod 1986;12:337-9.

\section{Yazışma Adresi:}

Dr. Yakup ÜSTÜN

Department of Endodontics, Faculty of Dentistry,

Erciyes University,

Kayseri, Turkey

Telephone number: +90 35220766 66-

29130

Fax number: +903524380657

E-mail address: yakupustun33@hotmail.com 